\title{
UTILIZING NOVEL IN THE READING CLASS TO EXPLORE STUDENTS' VIEWPOINT OF ITS EFFECTIVENESS
}

\author{
Oktaviari Ayu Sasalia ${ }^{1}$, Fatimah Mulya Sari² \\ Universitas Teknokrat Indonesia ${ }^{1}$
}

oktasas1@gmail.com¹ ${ }^{1}$ fatimah@teknokrat.ac.id ${ }^{2}$

\begin{abstract}
The use of novel on reading skills was important as an efficient and effective media. The novel helped students evaluate their reading skills. This research aimed to investigate student's perceptions of the use of novels on reading skills. This research was a descriptive qualitative type. The subject of this research was English education students whose numbers were adjusted to the needs of the research, 22 students. This study was conducted at Universitas Teknokrat Indonesia, Bandar Lampung. The instrument of data collection used a questionnaire and interview. The data analysis method was descriptive qualitative. The results showed participants had a positive perception toward using interactive instruction with authentic literary texts, such as novels, on their reading ability. Hence, it can be concluded that the use of English novels can be an alternative way to improve their reading skills in the English learning process.
\end{abstract}

Keywords: Student's Perception, Novel, Reading Skills.

To cite this article:

Sasalia, O. A. \& Sari, F. M. (2020). Utilizing Novel in the Reading Class to Explore Students' Viewpoint of Its Effectiveness. Journal of English Language Teaching and Learning, 1(2), 56-60.

\section{INTRODUCTION}

Indonesian students for all levels are encouraged to learn and master English (Ayu \& Indrawati, 2018) due to its importance in the era of society 5.0 since the development of the English language has reached many aspects of school life, including technology, science (Utami, Aminatun, \& Fatriana, 2020), arts, and many others. In Indonesian formal education, English has been given from the elementary level up to the university level. English has become one of the compulsory subjects that are taught and tested nationally.

In English subjects, reading plays an important role because most of the information nowadays is presented in the form of text. Hence, reading skills are needed to be mastered by the students. According to Urquhart \& Weir in 1998, reading skill is a cognitive ability that a person can use when interacting with the written text. In the taxonomies given in the following paragraph, some skills seem more inclusive than others (Bojovic, 2010). Besides, reading skills are also important due to the education assessment systems in Indonesia. Almost all of the education assessment systems in Indonesia, such as the national exam, are done in the written form, in which there are a lot of texts that need to be comprehended.

Although reading skills are important to be learned, not all of the students can do this skill easily. Sometimes, the researcher found the student's lack of motivation in practicing reading. They have not aware of the importance of learning English in their life. They tend to that English is only one of the compulsory subjects in the class. There were some reasons why students had a lack of motivation in practicing reading skills such as the text which was too long and contained difficult vocabularies and the time allotment which was too short.

According to Sari \& Putri (2019), learners should be provided with user-friendly instructional media to help them build their knowledge of the language. English teachers are required to use effective teaching media to assist the students to learn the target language (Wahyudin, 2019) and lead them become an independent learner (Aminatun \& Oktaviani, 2019; Sari, 2020). There is a lot of efficient and effective media that can be used to teach reading skills attractively such as a novel, nonfiction text, short story, or poetry unit, magazine, comic, etc. The novel is one of the literary genres that are interesting to be analyzed. As one type of literary genre, a novel may 
depict various aspects of life. The novel is a picture of real-life and manners (Wellek \& Warren, 1976). The novel has special tragedies and complicated problems that related to real life and make the story more attractive.

English teachers are required to use effective teaching media to assist the students to learn the target language (Wahyudin, 2019). Novels are considered efficient and effective media if they can convey educational messages to the readers, with attractive packaging that has a special appeal to the readers. One of the advantages of novels as an educational medium is that the author in conveying his educational message can be manifested in light language but does not bore the reader. Through storylines and characters in novels, without having to teach as in the learning process. Indirectly the readers are not feeling taught or forced (Kholisoh, 2012).

The first previous research titled using an English novel to improve Saudi EFL reading skills showed the results were participants held positive attitudes about using interactive instruction with authentic literary texts, such as novels, in the Saudi EFL reading classroom (Alshammari \& Ahmed, 2019: 23). Moreover, the second previous research titled student's perception of using a novel as main material in the EFL reading course (Tsai, C. 2012: 103) showed the results were of pedagogical significance to EFL teaching in that they present how well a novel was received in an EFL class, the benefits it offered as well as the difficulties it entailed to the reading process.

In addition to providing data on student's perception towards the use of novels on reading skills, the uniqueness of this research in linking language learning with literature is by implementing one literary source such as a novel to teach the reading skill. There is limited research on student's perceptions towards the use of novels in reading skills, especially in high school.

Eggen \& Kauchak (1996) state that perception is the process people use to attach meaning to stimuli. In this research, perception is student's feelings and thoughts on their agreement or effort of the use of novel on reading skills. Based on the previous explanation, the researcher puts the question at this research: "what is the perception of the student towards the use of novel in reading skills?" The result of this study was supposed to provide proof of student impressions and perception on the use of English novels on reading skills.

\section{METHOD}

The type of research was qualitative research. The population of this study is English major students at Universitas Teknokrat Indonesia Bandar Lampung, in which 22 students become the sample that consists of 1 male and 21 female. The research instrument in this study was an interview and questionnaire. According to Welman (2001), the interview is a data-collecting method that usually involves personal visits to respondents at home or work. It meant that interview is a kind of conversation by asking the participant about the social world in their lives. A questionnaire is a tool to collect the information with the way to give a nonverbal question to answer written (Margono, 2007).

The questionnaire was asking about the subjects' perceptions of the use of novels on reading skills. The questionnaire is composed of three main sections. The first section covers the history of respondents to obtain the student's details. The second section is about students' reading novels perceptions, and the last section covers the level of agreement to reading English novels, consisting of five items with 5 levels of agreement on the Likert scale. After the data were collected, the questionnaire data was translated into numbers and analyzed using Microsoft Excel. The results were described in the descriptive statistic that includes frequency and percentage tables.

\section{FINDINGS AND DISCUSSION}

\section{Students' perceptions on the use of novels in the reading class}

The results of the research were presented in the form of a questionnaire. Based on the results of the questionnaire of 22 students at Teknokrat University, it could be described student's perceptions towards the use of novel on reading skills as follows:

Table 1. Students' Perceptions on the Use of Novels

\begin{tabular}{|c|c|c|c|c|c|c|}
\hline No & Questions & $\begin{array}{c}\text { Strongly } \\
\text { Agree }\end{array}$ & Agree & Neutral & Disagree & $\begin{array}{l}\text { Strongly } \\
\text { Disagree }\end{array}$ \\
\hline \multirow[t]{2}{*}{1} & I like reading novels. & 12 & 8 & 2 & 0 & 0 \\
\hline & & $(64.8 \%)$ & $(30,7 \%)$ & $(4,5 \%)$ & $(0 \%)$ & $(0 \%)$ \\
\hline \multirow[t]{2}{*}{2} & Reading a novel can be beneficial & 1 & 18 & 3 & 0 & 0 \\
\hline & $\begin{array}{l}\text { for me in language English } \\
\text { learning, especially in reading } \\
\text { skills. }\end{array}$ & $(3.1 \%)$ & $(81.9 \%)$ & $(9.6 \%)$ & $(0 \%)$ & $(0 \%)$ \\
\hline 3 & $\begin{array}{l}\text { Reading the novel helps me to } \\
\text { understand the cultural, social, } \\
\text { political, and historical }\end{array}$ & $\begin{array}{c}7 \\
(35,4 \%)\end{array}$ & $\begin{array}{c}10 \\
(50,3 \%)\end{array}$ & $\begin{array}{c}5 \\
(14.3 \%)\end{array}$ & $\begin{array}{c}0 \\
(0 \%)\end{array}$ & $\begin{array}{c}0 \\
(0 \%)\end{array}$ \\
\hline
\end{tabular}




\begin{tabular}{|c|c|c|c|c|c|c|}
\hline & $\begin{array}{l}\text { background and setting of the } \\
\text { novel. }\end{array}$ & & & & & \\
\hline 4 & $\begin{array}{l}\text { Reading the novel help me in } \\
\text { improving my overall vocabulary, } \\
\text { phrasing, and sentence structure. }\end{array}$ & $\begin{array}{c}6 \\
(21.3 \%)\end{array}$ & $\begin{array}{c}13 \\
(73,4 \%)\end{array}$ & $\begin{array}{c}3 \\
(5,3 \%)\end{array}$ & $\begin{array}{c}0 \\
(0 \%)\end{array}$ & $\begin{array}{c}0 \\
(0 \%)\end{array}$ \\
\hline 5 & $\begin{array}{l}\text { Reading the novel help me in } \\
\text { improving my overall reading } \\
\text { skill. }\end{array}$ & $\begin{array}{c}9 \\
(26,2 \%)\end{array}$ & $\begin{array}{c}11 \\
(66,4 \%)\end{array}$ & $\begin{array}{c}2 \\
(7,4 \%)\end{array}$ & $\begin{array}{c}0 \\
(0 \%)\end{array}$ & $\begin{array}{c}0 \\
(0 \%)\end{array}$ \\
\hline
\end{tabular}

The table showed that Student' perceptions towards the Use of Novel on Reading Skills in English Education students based on the five questionnaires put forward were having the same perception with conclusions agreeing. The most approved perception was the perception in the second statement, namely reading a novel can be beneficial for me in language English learning, especially on reading skills. This perception obtained a result value of $81.9 \%$. The percentage that got the lowest average score in that statement is neutral $(9.6 \%)$ which only three students.

Besides, the percentage of each perception could be described as follows. In the first statement, I like reading novels, which means getting the highest score of $64.8 \%$. The second statement, reading a novel in the English language can be beneficial on reading skill which most students choose agree on the percentage value $81.9 \%$. The third statement, reading the novel helps me to understand the cultural, social, political, and historical background and setting of the novel, with a percentage agree of 50.3\%. The four statements, reading novel help me in improving in my overall vocabulary, phrasing, and sentence structure, got a percentage to agree of $73.4 \%$. Fifth, reading the novel helps you in improving your overall reading skill with a percentage of $66.4 \%$.

Based on the percentage of each point of the perception statement, it could be stated that the students agreed towards the use of novels on reading skills, especially about I like reading novels. Thus it can be argued that the student's perceptual process was that the individual was aware of, for example, what was seen, or what was heard, or what was felt, namely the stimulus received through the sense organs. This process was the final process of perception and was of real perception. The response as a result of perception could be taken by individuals in various forms.

As explained by Walgito (2004) that in the perception process there needed to be attended as a preparatory step in that perception. This showed that individuals were not only subject to one stimulus, but individuals were subjected to various kinds of stimuli caused by their surroundings. However, not all stimuli got a response from the perceived individual. The stimulus that would be perceived or got a response from the individual depended on the attention of the individual concerned.

Therefore, it can be stated that the perception acquisition of English Education students can be influenced by several factors and differences in perceptions can also occur in several things. The perception of a person or group can be much different from that of other people or groups even if the situation is the same. Differences in perceptions can be traced to the presence of individual differences, differences in personality, differences in attitudes, or differences in motivation. The process of the formation of this perception occurs within a person, but perception is also influenced by experience, learning, and knowledge.

To provide further insight into the use of novels in reading skills based on their perceptions, the researcher decided to do an interview. Five respondents were successfully collected to answer questions about issues related to the use of novels in their reading skills. The result of the interview can be seen below:

S1 : "I am reading a novel in my spare time. But sometimes, I can spend more than 5 days a week when I reading a novel. Comedy and romance are the most genres that I like. I choose that genre because based on my point of view, those genre is very entertaining. I also prefer English novels to Indonesian because English novels will increase my English ability when I got more lexical from reading and I got more understand in reading English that will affect my reading comprehension."

S2 : "I prefer to read a romance novel. It is an interesting topic for me. Sometimes I tried to read English novels through Watt pad it helps me added new vocabulary and idioms. By using it, it trains me to scan and skim the text. It also trains me to guess the meaning."

S3 : "I often read a novel, almost every day. I like the romance genre because it entertains me. Both English and Indonesian I like. I haven't a specific reason but the English language increase me lots especially vocabulary and structure of the sentence. So, when I reading more novels, I got improvement in understanding the sentence."

S4 : "I read a novel in my spare time, I do like either humor or mystery fiction novel like Harry potter novel since it has an unpredictable storyline, and enjoyable. When reading novels, I read both languages, but frequently I read in Bahasa since it was 
quite difficult to find an English novel here. Except when I want to read an English one, then I look for an online novel. I use Bahasa when I want to understand the story. Besides, if I read an English novel and I found an uncommon word, then I look for the meaning of it. For my process of learning, reading a novel can help me to enrich my word choice, accent, and structure."

S5 : "I do like reading novels. For more than four days I am reading a novel in a week. Romance novels are my favorite genre. Because it makes me feel curious about what's next story of the novel. Since I want to increase my English skills, I prefer to read an English novel than an Indonesian novel. Using English novels not only giving me more new vocabulary but then I also train my reading ability."

Based on the interview above, most of them like reading the novel. they often read the novel on spare time. According to them, reading novels provides many benefits. one of them is to improve their reading comprehension skills. such as to enrich word choice, accent, and structure. As a result, it can be concluded that students have positive perceptions towards the use of novel on reading skills.

\section{CONCLUSION}

Reading skills should be mastered by the students. Reading skills play an important role in a student's reading development. However, there are some problems encountered by the students when they are trying to master this skill. A teacher is urged to help the students to cope with their reading problems. The novel helped students evaluate their reading skills. Hence, this research is trying to reveal student's perceptions towards the use of novels on reading skills. Based on the results and discussion it could be concluded, the most approved perception was a perception in the second statement, namely reading a novel in the English language can be beneficial on your reading skill. This perception obtained the highest value of $81.9 \%$. The perception that got the lowest score of the percentage was statement number fifth, namely reading novels helped me improve my overall reading skill, and the perception got a percentage score of 7,4\%. The result of the research showed that students had a positive perception of the use of novel on reading skills. From the students questionnaire the researcher concludes that students do believe that reading an English novel in English subtitles can be beneficial for them in their reading skills. Hence, after conducting the research, it can be concluded that the use of English novels can be an alternative way to improve their reading skills. The students should realize the importance of learning English, especially reading skills. Since this research only focused on perceptions, the further researchers who are interested in researching the same topic are suggested to research the benefits of novel and the impact on the student's reading skills.

\section{REFERENCES}

Abrams. (1981). A Glossary of Literary Terms. New York: Holt, Rinehart, and Winston.

Alshammari, H. A. \& Ahmed, E. A. (2019). Using an English Novel to Improve Saudi EFL Reading Skills. Education and Linguistics Research, 5(2).

Aminatun, D. \& Oktaviani, L. (2019). Memrise: Promoting Students' Autonomous Learning Skill through Language Learning Application. Metathesis: Journal of English Language Literature and Teaching, 3(2), 214-223.

Ayu, M. \& Indrawati, R. (2018). EFL Textbook Evaluation: The Analysis of Tasks Presented in English Textbook. Teknosastik: Jurnal Bahasa dan Sastra, 16(1), 21-25.

Biklen, S., \& Bogdan, R. C. (1992). Qualitative Research for Education: An Introduction to Theory and Method. London: British Library.

Bimo, W. (2004). Pengantar Psikologi Umum. Jakarta: Andi.

Bojovic, M. (2010). Reading Skills and Reading Comprehension in English for Specific Purposes. https://www.researchgate.net/publication/261213403

Eggen, P. \& Kauchak, D. (1996). Strategies and Models for Teachers: Teaching Content and Thinking Skills. Boston: Pearson. Gill, Richard. (1995). English Literature. Houndmills: Macmillan Press LTD.

Harmer, J. (2001). The Practice of English Language Teaching. Harlow: Pearson Education.

Kholisoh, Badiatin (2012) Novel sebagai Media Pendidikan (Studi Eksperimen Novel dalam Mihrab Cinta Karya Habiburrahman El Shirazy). Masters thesis, IAIN Walisongo.

McNamara, D. S. (2007). Reading Comprehension Strategies. New Jersey: Lawrence Erlbaum and Associates, Inc.

Pramestiya, A. (2013). Student's Perception of the Use of Powerpoint in Public Speaking Skills Classes. Satya Wacana Christian University.

Sari, F. M. (2020). Exploring English Learners' Engagement and Their Roles in the Online Language Course. Journal of English Language Teaching and Linguistics, 5(3), 349-361.

Sari, F. M. \& Putri, S. N. (2019). Academic Whatsapp Group: Expressing Students' Experiences in Writing Class. Teknosastik: Jurnal Bahasa dan Sastra, 17(2), 56-65.

Siregar, N. (2014). The Effect of Student's Perception of Learning Techniques and Critical Thinking toward Student's Reading Skill at Government Senior High Schools in Depok. DEIKSIS, 6(3), 153-228.

Tsai, C-h. (2012). Student's Perception of Using a Novel as Main Material in the EFL Reading Course. English Language Teaching, 5(8), 103-112. 
Utami, A. R., Aminatun, D., \& Fatriana, N. (2020). Student Workbook Use: Does It Still Matter to the Effectiveness of Students' Learning?. Journal of English Language Teaching and Learning, 1(1), 7-12.

Wahyudin, A. Y. (2019). E-Comics In Teaching: Using Comic Strip Creators To Enhance Junior High School Students' Writing Ability. Proceedings of the 2nd ICON ELTL, Bandar Lampung: November 16, 2019. Page. 126-133.

Welleck, Rene and Warren, Austin. (1976). Theory of Literature. Florida: Harcourt Brace \& World, Inc.

\section{BIOGRAPHY OF AUTHORS}

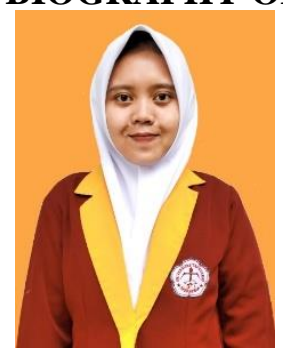

Oktaviari Ayu Sasalia is an active student in the English Education study program, Faculty of Arts and Education, Universitas Teknokrat Indonesia. During her study, she actively joins the students' organization.

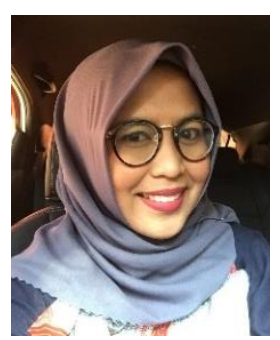

Fatimah Mulya Sari is an English Education Lecturer in the Faculty of Arts and Education, Universitas Teknokrat Indonesia. She discovers what she loves most about her works and where she hopes to take her career. She completed her Master's degree in Universitas Sebelas Maret in 2015. Her research interests are English language teaching, classroom interaction, classroom management, online/blended learning, and teaching methods. Recently, she is now the head of the Center for Education and Social Sciences, Universitas Teknokrat Indonesia. 